\title{
IN SEARCH OF A MULTTRELIGIOUS COMMUNITY IN A HUMANISED GLOBALIZATION
}

\author{
By: Ibrahim Abu Bakar*
}

\section{Abstract}

Globalisasi merupakan satu fenomena yang sangat sering didiskusikan oleh para sarjana. Hal ini karena ia memiliki dampak yang sangat besar bagi kehidupan manusia, khususnya terhadap agama dan spiritualitas. Paper ini adalah salah satu di antaranya, yang berupaya mengkaji dampak globalisasi terhadap manusia, khususnya pada umat Islam dan Kristen yang ada di Malaysia dan Swedia. Untuk konteks Swedia, penulis mendasarkannya pada tulisan Prof. Lande dari Swedia tentang isu-isu agama. Kemudian penulis memaparkan pandangan Malaysia terhadap komunitas multireligius. Sebagai kesimpulan dari tulisannya, penulis menyatakan bahwa sebuah komunitas multireligius dalam globalisasi yang humanis adalah sesuatu yang niscaya jika semua bangsa dapat jujur untuk mengakui dan mendukung kebebasan beragama.

\section{الملاصة}

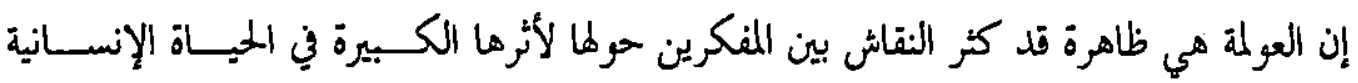

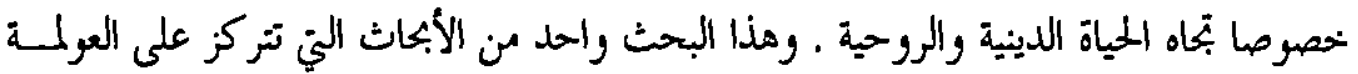

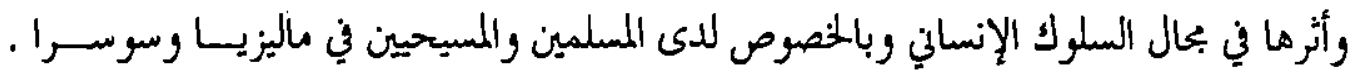

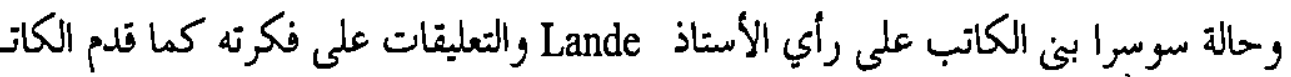
موقف ماليزيا بتحاه التعدد الأديان في البمتمع.

Key Words: Globalization, Multireligious Community, Freedom of Religion

\footnotetext{
- Professor of Universiti Kebangsaan Malaysia (UKM)
} 


\section{A. Introduction}

lobalization is one of the very pertinent topics among some scholars since globalization

has been seen as a new phenomenon effectings human cultures especially human attitudes toward religions and spiritualities. How and how far globalization has influenced human attitudes towards Christianity and Islam can been observed in Sweden and Malaysia. For this article, it is planned first to briefly sketch on globalization before it focuses on the religious issues in Sweden based on the paper written by Prof. Lande from Sweden, and then it makes some comments or remarks on those issues. Finally this article makes mention Malaysian attitude towards its multi-religious community.

\section{B. Globalization}

The effects of globalization can be observed in Sweden. Prof. Lande admitted that:

"Globalization changes the condition of our lives - and rocks our religious universe. The options increase with increased plurality. But traditional communities lose their grasp of people's mind. There is thus a dwindling number of missionaries in Church of Sweden going abroad for Church service. And there is a dwindling number of persons at home who really are concerned about what is going on in the so-called mission movements."'

On other page Prof. Lande acknowledged that "Globalization has thus thrown Swedish religiosity into turmoil. The old pattern Christian groups which balanced between Church of Sweden and Free Churches in an increasingly secular welfare society, have given way to a new situation. Key term is pluralism...." The term pluralism implies two meanings, the plurality of orientations as well as the plurality of Christian and non-Christian options. $^{2}$

From his viewpoint, globalization has changed the perception and attitudes of the Christian Swedes toward Christianity, churches and missionaries. Globalization has made Christian Swedes less enthusiastic and less committed toward the churches and missionary activities. This has to do with notions or isms associated with globalization and the relationship between globalization and religion.

There have been thinkers and leaders of globalization as well as supporters and opponents of globalization listed in the website globalizationguide.org There are surely many definitions of globalization. One of them says, "globalization is a process fueled by, and resulting in, increasing cross-border flows of goods, services, money, people,

I Aasulv Lande, 2004, "How Has Globalization Influenced the Swedish Religious Situation". The paper prepared for this international conference, p. 2.

2 Ibid., p. 4. 
information, and culture." Another one says that "Globalization, however, is also an ideology with multiple meanings and lineages."4

Prof. Luud, Professor of Globalization defines globalization "as a process in which geographic distance becomes a factor of diminishing importance in the establishment and maintenance of cross border economic, political and socio-cultural relations." Therefore, it is possible to see globalization as a process and as an ideology. The process is related to economic capitalist process. The ideology is associated with many ideologies around capitalism. The two prime movers of globalization are technology and ideology involving the rapid increase in cross-border economic and social exchange under capitalism. It has been associated with very liberal capitalism

There has been no agreement on the starting point of globalization. Some say that globalization started after the end of the Second World War with the development of multinational companies, the emancipation of colonies. Some say that globalization began after the fall of the Berlin Wall and the collapse of the Soviet Union. It is probably acceptable to see globalization as "basically a post-Cold War discourse prompted by the collapse of the Berlin Wall in 1989, followed by the break-up of the Soviet Union in 1991, and the emergence of a so-called 'unipolar' world led by the United States." Moreover, globalization "is closely connected to modemization and industrialization, key processes which have become the common goals of all nations in the world today."

Both modernization and industrialization can be considered as the main products of rationalism and empiricism that undermine the status and role of religion in human epistemological discourses. Rationalization, modernization and industrialization have developed in the West as matters of social, cultural and economic evolutions. Industrialization is part of modernization since economic activities are among the most important tangible cultural components. Modernization encompasses industrialization as well as other cultural components such as human attitudes, human beliefs and ethics. Both rationalism and empiricism are prevalent and dominant in modernization. Philosophies of modernization basically see all religions as the obstacles to human progress and perfection. For example, "the Church's demand for conformity to biblical teachings is a thinly veiled attempt to perpetuate ecclesiastical power and authority over its subjects." Thus the philosophies of modernization "advocate a new conception of knowledge, one

${ }^{3}$ Mauro F. Guillen, 2001, "Is Globalization Civilizing, Destructive or Feeble? A Critic of Five Key Debates in the Social-Science Literature," In Annual Review of Sociology, vol. 27 , p. 3.

${ }^{4}$ Ibid., p. 4.

${ }^{s}$ www.globalisationguide.org/01.html.

${ }^{6}$ Mohd Hazim Shah, 2000, "Globalization: Its Philosophical and Sociological Presuppositions." Akademika, 56 (January), p. 66. 
that is based on Rationalism and Empiricism, in which Reason and the evidence of the senses reign supreme, and in which science is the perfect exemplar."7

Logical positivism can be seen as a powerful intellectual product of rationalism and empiricism to undermine and finally possibly to make all religions obsolete or useless and harmful or dangerous. Since the major tenets of logical positivism consisted of the followings: "(1) the rejection of metaphysics in both its philosophical as well as its religious forms; (2) the establishment of a cognitive criterion based on logic and empiricism; (3) linguistic analysis as the key to conceptual clarification and the establishment of meaning; (4) the elevation of the status of science as the paradigm or model of human knowledge." $\mathrm{Hence}$, it is most likely that globalization does not look for religions and spiritualities such as Hinduism, Buddhism, Judaism, Christianity, Islam in its process and ideological formation.

\section{The Religious Issues in Sweden}

According to Prof. Lande, globalization has influenced the Swedish religious milieu after the Swedish people have encountered the immigrant Muslims and immigrant non-Muslims. Statistically, Prof. Lande, tells us that in Sweden, there are about 100,000 Muslims, 10,000 Jews, 8,000 or 10,000 Buddhists, and 1,000 Bahais, 1,000 Sikhs and 1,000 Hindus. ${ }^{9}$

Even though Prof. Lande does not provide us with the number of Christians in Sweden, we can assume that in Sweden the Christians are in the very large majority in comparison with the immigrant Muslims and immigrant non-Muslims. The immigrant Christians who mainly came from the former Soviet Union and the Middle Eastern dominated Muslim countries added up to the number of Christians in Sweden. Hence, the non-Christians are very marginal in comparison with the Christians in Sweden.

Prof. Lande also explains the origins of the immigrant Muslims in Sweden. The early phase of Muslims immigrated from the Soviet Union to Sweden during the last part of the $2^{\text {nd }}$ World War were the refugees. The second wave of Muslims immigrated to Sweden during the 1960 s when "Sweden as well as other European countries welcomed immigrants to meet the growing demands of the labour-market". During the high demand for the economic workers, the Muslims from Turkey and Yugoslavia immigrated to Sweden. They were the immigrants for the economic reasons. Later on, after the 1960 s onward, the Muslims from other countries immigrated to Sweden for other reasons especially persecutions claimed to be taken place in their home countries such as in North Africa, Pakistan, Palestine, Lubnan, Uganda, Iran, Bangladesh, Somalia, Albania and Yugoslavia. ${ }^{10}$

\footnotetext{
${ }^{7}$ Ibid., p. 72.

${ }^{8}$ Ibid., p. 76.

${ }^{9}$ Lande, 2004, "How Has Globalization....", p. 3.

${ }^{10}$ Ibid., p. 3.
} 
So as stated by Prof. Lande, there are three main reasons for the Muslims to immigrate to Sweden. Based on their immigration reasons, the immigrant Muslims in Sweden can be identified as the refugees, the economic workers and the protection or asylum seekers. Sweden is a secular democratic state. It seems that economic globalization and other transnational processes are omnipotent in Sweden. They are seen responsible for the problems of asylum and migration in Sweden. The fact that globalization has influenced these problems is felt by immigrants and refugees as well as by the Swedish people themselves. The Muslim immigrants and refugees and the nonMuslim immigrants and refugees in Sweden have confronted a great challenge in their efforts to preserve their own socio-religious identities. Their religious issues closely linked with their socio-religious identities. Some of the religious issues visible and identifiable in Sweden are mentioned in Prof. Lande's paper.

\section{The Religious Worshipping Places}

In Sweden, Prof. Land describes that two Muslim mosques were destroyed by: fire. One mosque was completed and consecrated in 1983; the mosque was located in Malmo, a commercial and industrial area, and then it was destroyed by fire in 2002 . The causes of the fire that burnt down the mosque in Malmo were not identified. Another mosque was built and completed in 1985 located in Trollhattan near Gothennurg in Southern Sweden but it was burnt down in 1993 and the causes of fire were identified and known. The three young boys were behind the setting fire on the mosque. They acknowledged their arson act and they did not like the presence of too many immigrants, Muslims and non-Muslims alike in Sweden. The Oriental Christian Church located not far from the Trollhattan mosque was thrown a fire bomb. ${ }^{11}$ How far and how serious of hateful situation of the Swedish young generation towards the immigrant Muslims and immigrant non-Muslims are not described by Prof. Lande. We also do not know if the Muslims were able to rebuild the two burnt down mosques.

There are Christian groups in Sweden "have argued against the establishments of mosques. However, the majority of Church of Sweden as well as Roman Catholic leadership has been supportive of the Muslim cause." They supported the project to build a mosque in Stockholm. ${ }^{12}$

From my understanding, all religious communities direly need to have their own religious worshipping places. The Muslims in Sweden as well as in other countries badly need to have a mosque in their locality or vicinity because of their religious duties to be carried out in the mosque. For example, in Muslim Sunnite Shafi' ite law, the male Muslims are obligatory to perform the Juma'at prayer in the mosque on every Friday at the after noon. The male Muslims are also recommended to perform their five obligatory daily

\footnotetext{
"Ibid., p.4.

${ }^{12}$ Ibid., p. 5.
} 
prayers in the mosque in group led by an Imam or the leader of the prayers. Hence, the mosque is a very crucial religious institution for the Muslim community. If the Christians are requested to attend their churches on every Sunday morning as I see in Malaysia, the Muslims are obligatory to attend their mosques on every Friday for the noon prayer and they are recommended to perform other obligatory prayers in groups in the mosques.

In addition to the prayers, the mosque for the Muslims is a learning centre. The Muslims and their children can go to the mosque to learn about Islam. The mosque is also for the Muslim religious festivals and other religious gatherings and activities. Like a church, a mosque is sometimes used as a place for Muslim brides and bridegrooms to solemnize their marriages.

From my viewpoint, a humanized globalization needs to acknowledge and defend the rights for the religious communities to have their religious worshipping places such as mosques for Muslims, churches for Christians, temples for Buddhists, Sikhs and Hindus, and synagogues for Jews. Having different worshipping places for different religious communities has to be seen as a humanized globalization. Islam teaches Muslims not to deprive other religious communities from having their worshipping places. This inference is based on the Qur'an (Surah al-Kafirun 109 and Surah al-Hajj 22). Surah 109 explains that Muslims will not worship what non-Muslims worship, and they have to worship differently. Surah 22: 40 explains that God did check one set of people by means of another people in order not to pull down monasteries, churches, synagogues and mosques.

\section{E. The Negative Attitude Towards Islam and Muslims}

Regarding the negative attitude and outlook of some of the Christians towards Islam and Muslim in Sweden, Prof. Lande writes that certain Christian groups such as "Free Church Christians or Christians with background in Turkey and the Middle East" bearing "testimonies of persecutions and instances of intolerance in Muslim lands" have strongly opposed Islam and Muslims and they have argued that "The Koran is dangerous, as it recommends violence. The Muslims are expected to hate their enemies whereas the Bible teaces [teaches] that we should love one another and in tercede [intercede] for our enemies..... Among Swedish Christians there are anti Muslim arguments on behalf of suppressed women. Christians have also criticized Islam from an exclusivist Christian position where the difference between the objects of faith is underlined. Christianity is furthermore seen as a religion which promotes democracy, contrary to legalist Islam."'13

As regards the negative attitudes and outlooks of some of the Christians in Sweden toward Islam and Muslims, they are surely not limited to Sweden. There has been the global campaign against Islam and Muslims. "That Islam is the single most important threat to world peace and security is a notion that is growing popularity and

${ }^{13}$ Ibid., p. 4-5. 
acceptability today. This is easily verified by even the most cursory examination of the headlines and reports that litter the newspapers, journals and news programs all over our increasingly globalized world."14

Among the demonizing images of Islam and Muslims in the United States are as follows: "For too many Americans, 'Muslim' means 'Terrorist', 'Islam' means "Violence". ${ }^{15}$ The Americans have such bad images of Islam and Muslims due to certain reasons.

"The images of Muslims in America directly descend from the image of Islam in the West....There have been distrust and misunderstanding between these two world cultures, occasionally based on real conflicts of interest or world views, but more often stemming from simple ignorance. The ignorance of Muslims as well as the ignorance about Muslims has thus contributed to creating... a climate of fear and distrust between Muslim-Americans and their fellow citizens.Alienation, ignorance, suspicion and institutional obstacles to integration have thus been among the key factors that have led to the systematic marginalization of Muslims in the US....". ${ }^{16}$

Among the negative attitudes and outlooks toward Islam and Muslims in Sweden as in Prof. Lande's paper are the following: 1. "The Koran is dangerous, as it recommends violence. The Muslims are expected to hate their enemies...."2. Islam and Muslim suppress women. 3. Legalist Islam does not promote democracy while Christianity does. ${ }^{17}$

The answers or responses to the three negative images listed above depend on the approaches to Islam and Muslims. Muslims themselves have different approaches to the Koran, the prime or most important source of theology, law and ethics. Other sources of Muslim theology, law and ethics are the Sunnah of the Prophet Muhammad, the qiyas (analogical deduction or reasoning), the ijma' (the Muslim consensus concerning a specific issue). The four sources of Islam are accepted by the Muslims who follow the Muslim legal or juristic school founded by the famous Muslim jurist and traditionist scholar Muhammad ibn Idris al-Shafi'i (767-820 A.C)

The approaches to the Koran and the Sunnah among Muslims can be divided into literalism, traditionalism, rationalism, circumstantialism and modernism. In the early Muslim history, the Kharijites, al-khawarij, were the advocates of literalism and traditionalism. They were originally part of Ali's soldiers but turned against Ali, the fourth

${ }^{14}$ Farish A. Noor, 1997, Terrorising the Truth [:] The Shaping of Contemporary Images of Islam and Muslims in Media, Politics and Culture. Penang (Malaysia): Just World Trust (JUST), p. 1.

${ }^{15}$ Ibid., p. 4.

${ }^{16} \mathrm{Ibid}$., p. 4-5.

${ }^{17}$ Lande 2004, "How has Globalization...",p. 5. 
Muslim pious caliph, because of their approach toward the Qur'an and the Sunnah and the new events taking place during their times. They refused to accept the understanding and interpretation of the Koran and the Sunnah advanced by Ali. They judged Ali as an infidel on the ground that Ali did not obey what the Koran commands Muslims to do. They understood that the Koran prohibited Muslims from looking for peace through negotiation with their enemies. The enemies in this case were $\mathrm{Mu}^{\text {'awiyah and his soldiers }}$ who did not recognize Ali bin Abi Talib as the caliph and fought against him and his soldiers in the Battle of Siffin. In that battle, Ali's soldiers almost won over Mu'awiyah and his soldiers. 'Amr bin al-'As who was leading Mu lawiyah's armies decided to stop the war by calling Ali's armies to return to the Koran for the solution.

The call to return to the Koran divided Ali's armies into two opposite blocs. One bloc wanted to temporarily stop the war and another bloc wanted to continue with the war. Finally the former won over the latter and the cease-fire took place, and Abu Musa al-Ash'ari was selected to represent Ali in the negotiation with 'Amr bin al-'As who represented Mu'awiyah. The result of the negotiation was not accepted by Ali's armies because Mu'awiyah was declared as the caliph by 'Amr. Ali's armies who opposed the negotiation became Ali's enemies and they were known as the Kharijites and Ali had to fight against them in the battles at Harura and Nahrawan. Hence, Ali was opposed by

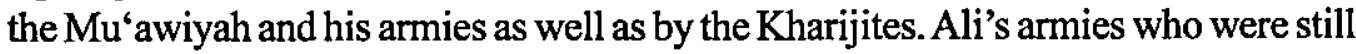
obedient to him known later on as the Shi' ites (the supporters ofAli). The Kharijites also opposed $\mathrm{Mu}$ 'awiyah. Finally, Ali was murdered by the killing squad formed by the Kharijites intended to kill Ali, 'Amr and Mu'awiyah. Ali was killed near the mosque in the early morning when Ali was walking to the mosque to perform the early morning obligatory prayer, salah al-subh. Ali became the caliph about five years only, from 35A.H./656.A.C to $40 / 661 .{ }^{18}$

From my viewpoint, the wars between the Kharijites and Ali and his soldiers were basically due to the different approaches to the Qur'an and the Sunnah. The Kharijites advocated literalism and traditionalism leading to fanaticism and radicalism. They totally refused to use some rational and circumstantial arguments to solve the problems confronted by the Muslims themselves. Ali understood the Qur'an and the Sunnah different from the Kharijites' understanding. It is possible to identify Ali's understanding contains the elements of rationalism and circumstantialism. For example, in their arguments against Ali, the Kharijites argued that Ali was religiously wrong in not taking the prisoners of war from the Battle of Camel. Ali argued that they were Muslims and they could not become the prisoners of war. The Muslims who opposed Ali in that battle was the "Aishah binti Abi Bakr, the widow of the Prophet Muhammad.

${ }^{18}$ Ibrahim Abu Bakar, Abdul Shukor Husin, and Mudasir Rosder, 2000, Al-Firaq alIslamiyyah PB3413. Bangi: Pusat Pengajian Jarak Jauh, UKM, p. 82-88. 
The Kharijites were the first radical Muslim religious sect in Muslim history. In their political theory, the Kharijites established the right to revolt against the Muslim unjust rulers or leaders. Therefore, they constantly revolted against the Umayyad and Abbasid caliphs and their governors because they were considered unjust. The right to revolt against the unjust Muslim rulers or leaders were less acceptable to the Muslim Sunnites because they preferred to avoid the traumas of civil wars and the lawlessness.

I tend to agree with Arberry's view saying that there is the problem of the relationship between revelation and reason in Judaism, Christianity and Islam. "Each system of beliefs resting upon faith in a Divine revelation introduces its own distinctive set of variations; all these variations need to be studied if the theme itself is to be appreciated in all its fecund richness." ${ }^{.19}$ Hence, the problem between the Kharijites and Ali can be seen as the problem of the relationship between revelation and reason in finding the solutions to the Muslim problems themselves.

Regarding the relationship between Muslims and non-Muslims, here again Muslim jurists have different views because of their different understanding of the Koran and the Sunnah. Some Muslim jurists understood that Muslims have to fight against non-Muslims until they become Muslims. This juristic view is literalist and traditionalist and it does not take into consideration the Koranic verses which prohibit any religious conversion by force such as the Koran (2:256) saying that let there be no compulsion in religion, the Koran (18:29) saying that the truth is from your Lord. Let him who will, believe, and let him who will, reject it, the Koran (10:108) saying that Oh ye men! Now Truth had reached you from your Lord! Those who receive guidance, do so for the good of their own souls, and those who stray, do so to their own loss, the Koran (109:6) saying that for you (non-Muslims) your religion, and for me [Muslims) mine. The Koran (6:108) also prohibits Muslims from reviling non-Muslims who worship other than Allah.

Some Muslim jurists conceptualized three types of relationships between Muslims and non-Muslims namely the abode of Islam or the territories belonging to or ruling by Muslims; the abode of war or the territories belonging to or ruling by the enemies of Muslims; and the abode of non-belligerence or the territories considered neutral or nonhostile to Muslims. The great majority of Muslim jurists advocated that Muslims can make treaties with non-Muslims who do pose a real danger to Muslims. The treaties of non-aggression between Muslims and non-Muslims are permissible and recommendable. The Koran (60: 8-9) says that Allah does not forbid you from dealing kindly and justly with those who do not fight you for your religion and do not drive you out of your homes, and Allah forbids you from dealing kindly and justly with those who fight you for your religion and drive you out of your homes, and support others in driving you out from your

${ }^{19}$ A.J. Arberry, 1965, Revelation and Reason in Islam, London: George Allen \& Unwind Ltd, p. 7. 
homes. The Koran (29:46) asks Muslims to speak with means better with the People of the Book (the Jews and Christians) if they do not inflict you with wrong and injury.

The view that Islam and Muslims are unjust to women. This view is due to Muslim traditionalists' and literalists' understanding of the Koran and the Sunnah. Muslim rationalists and modernists do not agree with the views regarding the status and rights of women as upheld by Muslim traditionalists and literalists. In Malaya, for example,

"Malayan Muslim modernists also struggled to liberate Muslim women from the religious and customary domination of the Muslim traditionalists. The traditionalists were more conservative and restrictive than Muslim modernists in their stance regarding the status and role of women in Islam. Muslim traditionalists also imposed more restrictions upon Muslim women than upon Muslim men."20

Riffat Hassan presented the different views of Muslim scholars on the status and roles of Muslim women in Muslim history and adamantly advocated that

"the Koran... does not discriminate against women despite the sad and bitter fact of history that the cumulative (Jewish, Christian, Hellenistic, Bedouin, and other) biases which existed in the Arab-Islamic culture of the early centuries of Islam infiltrated the Islamic tradition, largely through the Hadith literature, and undermined the intent of the Koran to liberate women from the status of chattel or inferior creature, making them free and equal to men.... In fact, when seen through a nonpatriarchal lens, the Koran goes beyond egalitarianism."2l

Hassan expressed his bewilderment towards the Western attitude to help and protect Muslim women's rights. Hassan wrote:

"In the midst of so much hatred and aversion towards Islam and Muslims in general, the outpouring of so much sympathy, in and by the West, towards Muslim women appears, at a surface level, to be an amazing contradiction. For are Muslim women also not adherents of Islam? And are Muslim women also not victims of 'Muslimbashing'? Few of us can forget the brutal burning of Turkish Muslim girls by German gangsters or the ruthless rape of Bosnian Muslim women by Serbian soldiers."22

For Hassan, Islam is "a religion of justice". For him, "God, who speaks through the Koran, is characterized by justice, and it is stated clearly in the Koran that God can

${ }^{20}$ Ibrahim Abu Bakar, 1994, Islamic Modernism in Malaya [:] The Life and Thought of Sayid Syekh al-Hadi 1867-1934. Kuala Lumpur: University of Malaya Press, p. 133.

${ }^{2 !}$ Rifaat Hassan, 2002, "Is Islam a Help or Hindrance to Women's Development?" In Islam in the Era of Globalization, Edited by Johan Meuleman. London: Routledge Curzon, p. 203.

${ }^{22}$ Ibid., p. 207. 
never be guilty of zhulm. Hence, the Koran, as God's Word, cannot be made the source of human injustice, and the injustice to which Muslim women have been subjected cannot be regarded as God-derived. The goal of Koranic Islam is to establish peace which can only exist within a just environment." ${ }^{\text {"23 }} \mathrm{He}$ proposed the development of " $\mathrm{feminist}$ theology' in the context of the Islamic tradition... in order to liberate not only Muslim women, but also Muslim men, from unjust social structures and systems of thought which make a peer relationship between men and women impossible."24

As regards the view that Islam does not promote democracy, this is also due to Muslim histories from the classical and medieval periods to the modern period. Many Muslim rulers were hereditary such as the Umayyads, the Abbasids and the Ottomans. The hereditary Muslim rulers were deposed by the revolutionary Muslim leaders such as Gamal Abdul Nasir, Mu'ammar Gaddafi and Mustafa Kamal Attaturk in the modern Egypt, Libya and Turkey respectively.

There have been Muslim scholars who think that Islam does not oppose democracy, pluralism and human rights. "Muslims have been convening conferences on the need to democratize and liberalize politics, society and thought. One might be surprised to know that the majority of fundamentalist theoreticians are now engaged in developing Islamic doctrines on democracy, pluralism and human rights. ${ }^{225}$ Among the objectives of the Center for the Study of Islam and Democracy in Washington D.C., are to promote study Islamic teachings promoting democracy and to promote democracy among the Muslim nations. The centre holds seminars and publishes works on Islam and democracy.

\section{F. Malaysian Case}

If we compare between Sweden and Malaysia, we find that Malaysia is a democratic secular nation-state like Sweden but Malaysia is different from Sweden in certain respects. First, the Muslims are not in large or great majority in comparison with non-Muslims in Malaysia. Meanwhile, the non-Muslims namely the Christians in Sweden are in large majority in comparison with the Muslims.

Second, Malaysia makes Islam the religion of the Federation of Malaysia by written down in the Federal Constitution of Malaysia in Article 3 (1) stating, "Islam is the religion of the Federation, but other religions may be practised in peace and harmony in any part of the Federation." In this sense, secularism in Malaysia is less powerful than secularism in Sweden. Islam in Malaysia can be regarded as the supporting pillar of the

${ }^{23}$ Ibid., p. 203.

${ }^{24}$ Ibid., p. 204.

${ }^{25}$ Ahmad S Moussalli, 1997, "Discourses on Human Rights and Pluralistic Democracy," In Islam in Changing World Europe and the Middle East, p. 45-90. Edited by Anders Jerichow and Jorgen Baek Simonsen. Richmond: Curzon Press, p. 45. 
state even though the state itself does not become a religious institution. It is probably due to the status of Islam in the Federal Constitution of Malaysia, Dr. Mahathir Mohamad, the fourth Malaysian Prime Minister declared that Malaysia is an Islamic state. He stepped down on 31 October 2003 and Abdullah Badawi succeeded him as the fifth Malaysian Prime Minister. Meanwhile the opposition political party named Pan-Malaysian Islamic Party (PMIP or in Malay PAS) does not agree. For PMIP, Malaysia is a Muslim state on the ground that Malaysia is ruled by Muslim leaders and Malaysia does not implement Islamic criminal law. Another opposition political party named Democratic Action Party (DAP) led by the Chinese maintains that Malaysia is a secular democratic nation-state. DAP refuses to acknowledge Malaysia as an Islamic or Muslim state.

Third, Malaysia has two legal systems: the secular and the Islamic. The secular legal system is for all Malaysians regardless of their religious affiliations, and the Islamic legal system is for the Muslims only. Sweden has only the secular legal system.

The Federal Constitution of Malaysia guarantees the freedom of religion in its article 11. The Article 11 (1) states, "Every person has the right to profess and practice his religion and, subject to Clause (4), to propagate it."Article 11 (2) states, "No person shall be compelled to pay any tax the proceeds of which are specially allocated in whole or in part for the purposes of a religion other than his own." Article 11 (3) states, "Every religious group has the right- (a) to manage its own religious affairs; (b) to establish and maintain institutions for religious or charitable purposes; and (c) to acquire and own property and hold and administer it in accordance with law."

The freedom of religion in Malaysia is not absolute. Malaysian religious people are restricted by two other clauses of Article 11 . Article 11 (4) states that the state law and the federal law "may control or restrict the propagation of any religious doctrine or belief among persons professing the religion of Islam". It is understood that other religious adherents cannot spread their religious beliefs and doctrines among the Muslims in Malaysia. The freedom of religion is also restricted by general law related to public order, public health or morality. Article 11 (5) states, "This article [Article 11. Freedom of religion] does not authorize any act contrary to any general law related to public order, public health or morality."

In short the freedom of religion in Malaysia is not much different from the freedom of religion stated in Article 9 (1) and (2) of the European Convention on Human Rights. The only difference is that the Muslims in Malaysia are not easy to convert to other religions. However, there is no written law prohibiting the Muslims in Malaysia from converting to other religions. If they do, they are socially, religiously rejected by their parents and families.

Regarding the status and roles of women, Muslim and non-Muslim women, I agree with Judith Nagata regarding the position of women in Malaysian Islam. She writes, "it is clear that in the Malaysian (and UMNO) vision of development, women are expected 
to play a substantial role. Women are involved equally with men in higher education and overseas training programs and are employed widely in public, private and professional sectors, which today includes two senior cabinet ministers." ${ }^{26}$

For the very recent number of women in the Malaysian cabinet ministers nominated after the general election held on 21 March 2004, there are three Muslim women ministers out of thirty-one ministers; they are Rafidah Aziz, Shahrizat Jalil and Azalina Othman Said. There are three women deputy ministers namely Dr. Ng Yen Yen, Kamsiyah Yeop and Azizah Mohd Don out of forty deputy ministers, and five women parliamentary secretaries out of twenty parliamentary secretaries. The women who become the parliamentary secretaries are Dr. Mshitah Ibrahim, Dr. Tan Yee Kew, P. Komala Devi, Noriah Kasnon, Rohani Abdul Karim and Chew Mei Fun. ${ }^{27}$

\section{G. Concluding Remarks}

A multireligious community in a humanised globalization is possible and viable if all nation-states in the globalised world sincerely and frankly acknowledge and defend the freedom of religion. Malaysia, for example, has included in its federal constitution the freedom of religion. So far all religious rights related worshipping places, the properties belong to religious bodies, religious education, rituals and practices as well as religious festivals and celebrations are legally acknowledged and respected in Malaysia. However, the freedom of religion and the religious rights in Malaysia are within the limitations as they are prescribed by laws necessary to protect public safety, public order, health or morals and the rights and freedoms of others.

26Judith Nagata, 1994, "How to be Islamic without Being an Islamic State [:] Contested. Models of Development in Malaysia," In Islam, Globalization and Postmodernity, Edited by Akbar S. Ahmad and Hăstings Donnan. London: Routledge, p. 78.

${ }^{27}$ New Sunday Times, March 28, 2004. 


\section{BIBLIOGRAPHY}

Arberry. A. J, 1965, Revelation and Reason in Islam, London: George Allen \& Unwind Ltd.

Council of Europe, "The European Convention on Human Rights." (See, http:// www.hri.org/docs/ECHR50.htm1), visited 5 April 2004.

Farish A. Noor, 1997, Terrorising the Truth [:] The Shaping of Contemporary Images of Islam and Muslims in Media, politics and Culture. Penang (Malaysia): Just World Trust (JUST).

Guillen, Mauro F., 2001, "Is Globalization Civilizing, Destructive or Feeble? ACritic of Five Key Debates in the Social-Science Literature," In Annual Review of Sociology, vol. 27 (2001).

Ibrahim Abu Bakar, Abdul Shukor Husin, and Mudasir Rosder, 2000, Al-Firaq alIslamiyyah PB3413. Bangi: Pusat Pengajian Jarak Jauh, UKM.

Ibrahim Abu Bakar, 1994, Islamic Modernism in Malaya [:] The Life and Thought of Sayid Syekh al-Hadi 1867-1934. Kuala Lumpur: University of Malaya Press.

International Law Book Services, 1995, Federal Constitution, Kuala Lumpur: International Law Book Service.

International Society for Human Rights, 2004, "Islamic Jurisprudence and Its Sources. Frankfurt: International Society for Human Rights"(http:/www.ishr.org/activities/ campaigns/stoning/background.htm), visited 30 March 2004.

Khaled Abou El Fadl, 2001, "Islam and the Theology of Power," In Middle East Report 221, Winter 2001.

Lande,Aasulv, 2004, "How Has Globalization Influenced the Swedish Religious Situation". The paper prepared for this international conference.

Mohd Hazim Shah, 2000, Globalization: Its Philosophical and Sociological Presuppositions. Akademika, 56 (January). 
Moussalli, Ahmad S., 1997, "Discourses on Human Rights and Pluralistic Democracy," In Islam in Changing World Europe and the Middle East, Edited by Anders Jerichow and Jorgen Baek Simonsen. Richmond: Curzon Press.

Nagata, Judith, 1994, "How to be Islamic without Being an Islamic State [:] Contested Models of development in Malaysia," In Islam, Globalization and Postmodernity, Edited by Akbar S. Ahmad and Hastings Donnan. London: Routledge.

New Sunday Times, March 28, 2004, The Abdullah Administration March 27.

Rifaat Hassan, 2002, “Is Islam a Help or Hindrance to Women's Development?" In Islam in the Era of Globalization, Edited by Johan Meuleman. London: RoutledgeCurzon. 